\title{
The Unscientific Science Education
}

By

Prof. Medhat A. Elnemr

Prof. Hala M. Tolymat

The goal of preparing an enlightened scientifically literate citizen was central to attempts to develop and reform science education for the second millennium (American Association for the Advancement of Science (AAAS) 1990; 1993, National Research Council (NCR) 1996; Miller \& Osborne, 1998; National Science Teachers Association (NSTA), 2000). Despite the mottos calling for targeting the development of scientific thinking, research skills, and creative abilities through science education the content of the science curriculum at all stages (particularly in Egypt) is almost completely devoid of "the language of science, and the concepts and processes of scientific inquiry." (Elnemr, 1982, 1988, 1991a).

The essence of scientific endeavor is the intricate interaction between fact and theory. In such an exchange, scientists deal with nature and verify their ideas through observations, questions, hypotheses, experimentation, data analysis, and model building, etc. In this context of the inquiry, scientists develop concepts through inference and verify theories in view of the evidence.

Science researchers and scholars use important terms and definitions, such as Variables, Sampling, Measurement, Observation, Scientific question, Hypothesis, Experimental design, Experimental and control groups, Cause-and-effect, Correlation, Statistical significance, Objective verification of 
knowledge, etc. In the absence of the above concepts and processes from the educational endeavor, the nature of science will be obscured (Elnemr, 2018; Tolymat,2001).

The phrase 'nature of science (NOS)' typically refers to the epistemology of science, science as a way of knowing, or the values and beliefs inherent to the development of scientific knowledge (Lederman 1992; Elnemr 1997). Beyond this general characterization, there is currently no clear consensus between philosophers and historians of science, practicing scientists, and scientific education specialists on a specific definition of the nature of science (Lederman, 2000). This lack of agreement, however, should not be alarming given the multifaceted, complex, and dynamic nature of the scientific endeavor. Conceptions of NOS have changed with developments in various scientific disciplines. A case in point is the 'leap' from a classical deterministic approach in physics to a quantum indeterministic conceptualization of the discipline. The change in the concept of the nature of science has coincided with developments in the history, philosophy, and sociology of science: areas that have consistently studied the scientific endeavor itself. These developments, in turn, led to changes in the methods adopted by specialists in science education in schools and universities- globally and locally- in the definition of the nature of science since the beginning of the twentieth century. Kuhn (1970) explained the role of social, psychological and cultural aspects in shaping and influencing scientific endeavors. The difficulty of separating thought from observation was therefore discussed on the basis that observation is often in an empirical context related to particular theory-laden observations and that beliefs and preconceptions often determine the direction and purpose of our perceptions. These conceptual theoretical frameworks are what Kuhn (1970) called "the paradigm", Lakatos (1979) 
called "programs and traditions", and Collins (1985), called "science studies". The paradigmatic and revolutionary approach marked a new shift in philosophy - and the history of science, from the emphasis on the context of proof to exploration in the context of discovery and exploration of the role played by various factors during the development of science. Evidently, the second half of the twentieth century witnessed the emergence and continuation of a new philosophy of science and a new perspective of its nature and structure.

Despite the slight differing views on the nature of the scientific endeavor, a common framework rejects supreme determinism (which was challenged later by modern concepts of quantum physics, non-determinism, and relativity). The contemporary philosophy of science emphasizes that although scientific research methodology and procedures remain valid as a human attempt to understand deeply the physical cosmic existence, the scientific method will always be far from complete and is "a way of knowledge" rather than "the way of knowledge". Science develops in the process of developing approximate mental conceptions that show, to a certain extent, the connections in the fabric of nature and in the whole universe. This can be done only through conceptual work, analyzing nature and building physical and mathematical models is personal creativity and high-level imagination, and this human spirit is what the scientific endeavor all about.

Reforms in science education all over the world advocate a view of teaching and learning science that emphasizes inquiry to learn about the nature of science (NOS) and increase interest in science (e.g., European Commission, 2007; Quinn, Schweingruber, \& Keller, 2012). However, research reveals that practices of scientific inquiry in schools and universities do not reflect a contemporary view of NOS (Capps \& Crawford, 2012; Grandy \& Duschl, 2008; Tolymat, 2001). If 
the content and methods of science education at all levels of sophistication across the educational system do not represent the nature of science, science teaching/ learning will be reduced to narrow expository narration of scientific findings and conclusions. Consequently, processes of scientific inquiry will be replaced by superficial "activities" only to satisfy the official "National Standards" requirements. In this case, the student will view science as disconnected topics and pieces of information good only as telegrams for memorizing (Elnemr, 2011).

\section{Purpose of the study}

- The development of an adequate vision of the nature of science has been a recurrent objective of science education, regardless of the level of education. Consequently, it has been- and still- considered an area of productive research characterized by several parallels, but different, lines of investigation.

- Status of vision or perception of the nature of science among those who are responsible for conveying scientific findings and discoveries to school and university students-let alone the public- was investigated through many empirical research studies in the past few decades. A comprehensive review of the empirical literature (both quantitative and qualitative) has yet to be done.

- This paper is an attempt to review those research studies that explored the level of perception/ vision of (NOS) of graduates and undergraduates of the faculties of science and education, as well as pre-service, in-service science teachers in Egypt and other countries.

- Most of the empirical studies used a variety of instruments that were substantially more or less addressing the current context or framework of national 
and international science education standards addressing NOS.

- This framework reflected the contemporary position of the scientific community regarding the agreed-upon vision of the nature of science, and it was based on the theses of NABT (1987); NAS (1998); AAAS, Benchmarks (1993); SAAWOK, Moore, 1993), and NRC(1996). A few thousand international specialists in natural sciences, and philosophy and educational societies accepted this framework. This framework of NOS standards represented the "criterion" on which most of the studies -reviewed in this paper- used to evaluate each sample members' responses regarding their perception/views of the nature of science (Ledermam, 1992; NRC; 1996, Coil, D., Wenderoth, M., Cunningham, M., Dirks, C., 2010).

- The framework included universal characteristics of the nature of contemporary science, which are summarized as follows:

- Science is a systematic process of collecting information through different types of direct and indirect observation processes, and verifying information by methods including, but not limited to, experimentation.

- The main product of science is the knowledge available in the form of concepts related to nature, laws, and theories related to these concepts.

- The reliability of Scientific knowledge does not contradict its relative tentativeness and adaptability.

- There are - and not just one - several methodological designs that characterize the 
scientific approach in trying to understand and interpret nature.

- Creativity is a vital element - although a personal aspect - in the production of scientific knowledge.

- Science is determined by research and investigation methods and explanations related to the observable natural universe and thus cannot use supernatural elements in the production of scientific knowledge.

- The main objective of science is the formation of explanatory theories and laws. The laws are generalizations or universal relations related to how certain aspects of the natural world behave under certain conditions.

- Theories are inferred interpretations that relate to certain aspects of the natural world, and they do not become laws even if they have more evidence.

- Well-established laws and theories must be consistent and compatible with the best available evidence and have successfully passed the test through a wide range of phenomena, observations, direct and indirect evidence.

- Individuals from all over the world contribute to the development and verification of scientific knowledge. Science does not exclude any race or category of human beings.

- Questions posed by science, observations, and conclusions reached are affected by the state of scientific knowledge, the social and cultural context of the researcher, as well as the experiences and expectations of the observer. 
- History of science reveals the evolutionary changes and the revolutionary changes science has endeavored.

- Although science and technology affect one another, basic research is not directly concerned with practical results, but rather in deepening the understanding of the natural world for itself.

This framework reflects the vision that science educators are expected to have at all stages of education (NSTA, 2000).

\section{Sample}

The science educators' samples participated in the reviewed studies included in clusters: undergraduate student teachers, in-service science teachers at secondary schools, and faculty members from a variety of institutions including numerous faculty and postdocs at the faculties of science and faculties of education in 25 countries ( .....Arab, ....). Each cluster was treated as a small-scale representation of the total population. The clusters were mutually exclusive and collectively exhaustive. Multiple cluster technique was employed: Science Educator-Country- Study. In each study, responses of particular science educators were summarized qualitatively into personal views/ perceptions of the nature of science as compared with the NOS framework used.

\section{- Findings and conclusions}

- Findings and conclusions

- The results and conclusions of the (37) reviewed studies were collected, summarized, and organized in the following points: 
- Most of the school science teachers had inadequate perceptions/views regarding the nature of science (NOS). The majority of these inadequate perceptions/views were below the pedagogically accepted level required for appropriate science teaching.

- School science teachers who lack the correct concept of interpretative science nature find it difficult to acquire correct scientific concepts

- Science departments in most colleges lack a formalized curriculum for teaching undergraduates science process skills.

- Faculty overwhelmingly support teaching undergraduate science process skills but typically do not spend enough time on teaching skills for the need to cover content.

- Many scientists' responses showed more alternative conceptions of NOS with respect to tentativeness, subjectivity, social and cultural embeddedness, and the relationship between scientific theories and laws.

- The scientists' views about NOS differed with few observable patterns within or across disciplines. The junior scientists' and experts' views of aspects of NOS were not substantially different.

- There was no significant difference in the conception of NOS between university science majors and nonscience majors.

- Preservice science teachers have views that are more unmodern and unrealistic views regarding scientific laws, hypotheses, and theories.

- Most of the in-service science teachers have misconceptions (alternative conceptions) about NOS in terms of understanding of the empirical and tentative nature of science, and the role of creativity in science and the relationship between theories and laws. 
- Most participants failed to explain the subjectivity of scientific knowledge and the distinction between observation and inference in the processes of science with aspects of the NOS.

\section{Implications of the study:}

- In light of the above results and conclusions, the study recommended the following:

- A way that always considers the genuine nature of science, in terms of its epistemology, history, methodology, and significance.

- Attention should be given to the NOS within undergraduate science majors as well as preservice science teacher's preparation programs.

- More professional development courses and activities should focus on teachers' understandings of NOS and ways to translate these understandings into classroom practice.

- Emphasize the method of science and NOS in all undergraduate introductory science courses.

- Highlight the process of scientific verification and NOS in all science textbooks and resources at university and pre-university education.

- Develop methods of teaching science commensurate with the developments of science and its operations.

- Participants' responses strongly suggested that explicitly teaching undergraduates' skills early in their education may enhance their understanding of science content.

- It appears that science educators who teach introductory courses find themselves in this conflicted position teaching undergraduates' content without the skills needed to help them master that content. It is with the 
best of intentions that faculty provide introductory science students with a foundation of content knowledge so that they may be better prepared to pursue science with passion.

- Science teacher preparation programs should be based on improving science teachers' conceptions of NOS with the anticipation that improved students' conceptions would necessarily follow.

- Scientists relay important information regarding issues such as the reliability of DNA evidence, global climate change, and the legality of drugs. Using this information, members of the public are expected to evaluate the evidence and arrive at a conclusion; actions closely determined by their views about science.

- However, many members of the public hold naïve views of science and scientific knowledge, confusing terms such as theory, law, and hypothesis. Many of these naïve views are also reflected in K-12 schools. Such a lack of understanding is problematic when attempting to bridge the gap between science and science within the context of society. For this reason, improving both teacher and student views about the nature of science has been an educational objective for more than fifty years.

- The study of science to which not only pre-service science teachers in the faculties of education but undergraduates of other parallel faculties are exposed does not provide the appropriate opportunity to form a deep and contemporary mature vision/ perception of the nature of the scientific endeavor.

- The vision that students of science teachers in faculties of education - despite its naiveté- have a limited ability to survive and survive longevity after leaving the university preparation stage, despite their involvement 
in the practice of teaching "science" and dealing with its concepts and processes. The type of "science" offered by school and university curricula seems to have a role in obscuring the contemporary vision of science, its dynamic concepts, and processes from the minds of many members of the community of science educators (Elnemr, 2011).

\section{Reviewed Arabic Studies}

1. Abdullah Y., Aboud A., Al-Hamdani, A. (2007). The Extent of understanding of the Nature of science among undergraduate students and its relationship to their thinking in the light of several variables, Journal of Education and Science, 14(1), 186 - 203. Iraq.

2. Alahmad, Nedal. (2018).The Perceptions of the Science Female Teachers of the Intermediate Schools Towards the Nature of Science NOS According to the Next Generation Science Standards NGSS. Journal of Scientific Research in Education 4 (19).471-495.

3. Alhosani, Sara.(2016). Perceptions of science teachers in the second cycle (5-10) of the basic education about the nature of science and its relationship to values of gender and years of experience (Unpublished Master's thesis). Sultan Qabous University. Oman.

4. Al-Khun, Dana. (2018). The level of understanding of the biology teachers in the directorate of Irbid for the nature of science and its relation to the level of their interpretation of biological phenomena (Unpublished Master's thesis). Yarmouk University. Jordan.

5. AlRashidi, Said Eid. (2014). The nature of the high school physics teachers in Tabuk Region of Saudi Arabia's beliefs about nature of science and their actual 
understanding for scientific concepts (Unpublished Master's thesis). Jordanian University, Amman, Jordan.

6. Altamimi, Rana. (2015).The Nature of science and scientific inquiry of the upper elementary science teachers and their relationship with the level of scientific understanding of controversial scientific issues and scientific attitudes (Unpublished doctoral dissertation). Yarmouk University. Jordan

7. Alzaanien, Gamal. (2016). The level of knowledge of science teachers' philosophy of science and its relationship to their teaching performance in secondary schools in Gaza Governorate. Journal of Scientific Research in Education, 17, 599-622.

8. Haidar, A. H. (1999). Emirates pre-service and inservice teachers' views about the nature of science". International Journal of Science Education 21(8), 807822.

9. Ibraheem, A. (2007). Middle school science teacher Tabook area understanding of the nature of science and the relationship of such understanding to tests experience and his preparation for achievement (Unpublished Master's thesis). The Jordanian University. Amman, Jordan.

10. Iqbal, H., Azam, S. , Rana, R. (2009). Secondary school science teachers' views about the nature of science. Bulletin of Education and Research, 31, (2), 29-44.

11. Iriz, O.S. (2004).Turkish preservice science teacher educators' beliefs about the nature of science and conceptualizations of science education. (Unpublished doctoral dissertation). The University of Nottingham, UK. 
12. Samara, Nawaf A.(2015). Understanding of the nature of science among undergraduate students at Mutah University in Jordan. European Scientific Journal 11 (8), 290-302.

13. Tolymat, Hala. (2001). Pre-service science teachers' vision of recent nature of science -an exploratory study. Journal of Science Education,4 (1), 1-31.

\section{Reviewed Non Arabic Studies}

1. Abd-El-Khalick, F. (2006). Over and over again: College students' views of nature of science. In L. B. Flick, N. G. Lederman (Eds.), Scientific inquiry and nature of science: Implications for teaching, learning and teacher education (pp. 389-425). Netherlands: Springer.

2. Chen, Sufen. (2001). Prospective teachers' view on the nature of science and science teaching. Unpublished Doctoral Dissertation, Indiana University.

Coil, David, Wenderoth, M., Cunningham, M., Dirks, C. (2010). Teaching the process of science: Faculty perceptions and an effective methodology. CBE-Life Sciences Education, 9, 524-535.

3. Dikmentepe, E., \& Yakar, Z. (2016). Preservice science teachers' views on science-technology-society. International Journal of Higher Education 5(2), 183195.

4. Dogan, N. Abd-El-Khalick, F. (2008). Turkish grade 10 students' and science teachers' conceptions of nature of science: A national study. Journal of Research in Science Teaching, 45 (10), 1083-1112. 
5. Dursun, B. \& Özmen, N. (2018). Science preservice teachers' views on nature of science and technology. Journal of Educational Sciences Research, 8 (1), 37-53.

6. Erdoğan, R. (2004). Investigation of the preservice science teachers' views on nature of science (Unpublished Master's thesis). Middle East Technical University, Graduate School of Natural and Applied Sciences, Ankara.

7. Halai, N., McNicholl, J. (2004). Teachers' conceptions of the nature of science: A comparative study from Pakistan and UK. School Science Review, 86(314), 93100.

8. Karakas, M. (2008). A study of undergraduate students' perceptions about nature of science. Bulgarian Journal of Science and Education Policy, 2(2), 233-249.

9. Khaldi, Mousa M. M. (2010). An exploratory study of Palestinian science teachers views of the nature of science. Unpublished doctoral dissertation, The University of Nottingham, UK.

10. Koc, Isil. (2009). In-service science teachers' views about the nature of science. Journal of Hasan Ali Yücel Faculty of Education, (11), 1-11.

11. Lau, K.C. (2011). Knowledge and skills that science teachers need for teaching the nature of science. Unpublished Doctoral Dissertation. University of Leicester. UK.

12. Lederman, N. G. (1992). Students and teachers' conceptions of the nature of science: A review of the research. Journal of Research in Science Teaching, 29(4), 331-359.

13. Lieu, S. (1997). Teacher understanding of the nature of science and its impact on students learning about 
the nature of science in STS/constructivist classrooms (Unpublished doctoral dissertation). The University of Iowa, Iowa City, Iowa. USA.

14. Liu, S. Y., Lederman, N. G. (2007). Exploring prospective teachers' worldviews and conceptions of nature of science. International Journal of Science Education, 29(10), 1281-1307.

15. Mellado, V., Bermejo, M. L., Blanco, L. J., Ruiz, C. (2007). The classroom practice of a prospective secondary biology teacher and his conceptions of the nature of science and of teaching and learning science. International Journal of Science and Mathematics Education, 6(1), 37-62.

16. Mintzes, J. J. (2007). Teaching science for understanding at MIT: Engaging the best and the brightest. Journal of Science Education and Technology, 16, (4), 365-368.

17. Murcia, K., Schibeci, R. (1999). Primary student teachers' conceptions of the nature of science. International Journal of Science Education, 21(11), 1123-1140.

18. Palmquist, B., Finley F. N. (1997). Preservice teacher' views of the nature of science during a post baccalaureate science-teaching program. Journal of Research in Science Teaching, 34(6), 595-615.

19. Park, Do-Yong. (2009). Different conceptions about the nature of science among pre-service elementary teachers of two countries. Journal of Elementary Science Education 21 (2), pp. 1-14.

20. Ryan, A. G., Aikenhead, G. S. (1992). Students' preconceptions about the epistemology of science. Science Education, 76(6), 559-580. 
21. Tira, Praweena. (2009). Comparing scientists' views of the nature of science within and across disciplines and expertise. Unpublished Doctoral Dissertation. Indiana University, USA. (Thailand)

22. Uma, Ryan.(2019). Investigating the nature of science understanding of pre-service elementary teachers in an integrated physical science course. Unpublished Master Thesis in Chemistry, College of Science and Mathematics California State University, Fresno, USA.

23. Wei, Bing, Li, Xiaoxiao. (2017). Exploring science teachers' perceptions of experimentation: implications for restructuring school practical work. International Journal of Science Education, 39 (13), 1775-1794. $(86$ science teachers).

24. Xu, Shan Shan. (2011). Study on chemical pre-service teachers views of nature of science. Unpublished Doctoral Dissertation. Northeast Normal University, People Republic of China.

\section{Resources}

(AAAS) American Association for the Advancement of Science . (1990). Science for all Americans. New York : Oxford University Press.

American Association for the Advancement of Science (AAAS) . (1993) . Benchmarks for Science literacy : Project 2061. New York : Oxford University Press.

Bryan, L. (2012). Research on science teacher beliefs. In B. J. Fraser, K. Tobin, C. J. McRobbie (Eds.), Second International 
Handbook of Science Education (pp. 477-495). Netherlands: Springer.

Capps, D. K., \& Crawford, B. A. (2012). Inquiry-based instruction and teaching about nature of science: Are they happening? Journal of Science Teacher Education, 1-30.

Collins, H. (1985). Changing order - replication and induction in scientific knowledge. London: Sage Publications.

Duschl, R. A., Grandy, R. (2013). Two views about explicitly teaching nature of science. Science Education, 22(9), 2109-2139.

Elnemr, M. (1982). Processes of science: a goal and method for teaching college physics. A paper presented at the Arab Conference on improving the Teaching of physics in the Universities. Held by the Egyptian Academy of Science and Technology. Cairo: 12-18 December.

Elnemr, M. (1988). Quantitative analysis of the inquiry component of high school science texts. Educational Studies, 3(12), 57-93.

Elnemr, M. (1991a). History and nature of science and technology in secondary school science textbooks. A paper presented at the sixth Conference of the New Education Association on Present and Future of Secondary Education, Ain-Shams University, Girls College, Cairo: 6-8 July.

Elnemr, M. (1991b). Science and technology issues in precollege science textbooks. A paper presented at the third annual conference of the Egyptian council of Curricula and Instruction (ECCI). Alexandria, Egypt: 4-8 August.

Elnemr, M. (2011). Revolutionizing science education in Egypt. A paper presented at the Fifteenth Conference of Egyptian Society for Science Education (ESSE). On Science 
Education: A New Thought for New Reality. Cairo: 6-7 September.

Elnemr, M. (2018). Educational Improvement: Mistakes in Diagnosis and Illusions in Treatment. A paper presented at the twenty seventh Conference of Egyptian Society for Science Education (ESSE). Preparing Teachers for Excellence: Cairo: 25-26 June.

Elnemr,M. (1997). Rationale and Requirements of Science Teacher Education for the Twenty First Century. A paper presented at the First Conference of Egyptian Society for Science Education (ESSE). On Science Education for the Twenty First Century. Alexandria: 10-13.

European Commission (2007). Science education now: A renewed pedagogy for the future of Eu $\neg$ rope. Brussels: European Commission, Directorate-General for Research. Hodson, D. (2009). Teaching and learning about science: Language, theories, methods, history, traditions and values. Netherland: Sense Publishers.

Kuhn, T. (1970). The structure of scientific revolutions. Princeton, NJ: Princeton University Press.

Lakatos, I. (1979). The methodology of scientific research programs. Cambridge: Cambridge University Press.

Lederman, N. (1992). Students' and teachers' conceptions of nature of science: Review of the research. Journal of Research in Science Teaching, 29 (4) ,331-359.

Lederman, N., \& Lederman, J. (2014). The next generation science standards (NGSS): Implications for preservice and inservice science teacher education. Journal of Science Teacher Education, 25(2), 141-143. 
Millar, R. \& Osborn, J. (1998). Beyond 2000 science education for the future. London: King's College.

National Academy of Sciences (NAS). (1998). Teaching about evolution and the nature of science. Washington, DC: National Academy Press.

National Association of Biology Teachers (NABT). (1987). scientific integrity: A position statement.

National Research Council (NRC). (1996). National science education standards. Washington, DC: National Academy Press.

National Science Teachers Association. (NSTA). (2000). The nature of science:An NSTA Position statement. Washington, DC: NSTA.

Quinn, H., Schweingruber, H., \& Keller, T. (2012). A framework for K-12 science education: Prac $\neg$ tices, crosscutting concepts, and core ideas: National Academies Press

Tolymat, Hala. (2001). Pre-service science teachers' vision of recent nature of science -an exploratory study. Journal of Science Education, (4) 4, 1-24. 